\title{
PARTIKEL FATIS BAHASA MANDARIN DALAM DRAMA TELEVISI: KAJIAN AWAL TERHADAP PARTIKEL $L E$
}

\author{
Hana Nurul Hasanah
}

\begin{abstract}
Abstrak
Salah satu ciri bahasa lisan dengan ragam tidak baku adalah penambahan partikel fatis di awal, tengah, atau akhir kalimat. Satu partikel fatis yang dapat dikatakan paling sering digunakan oleh penutur Bahasa Mandarin adalah partikel le. Penelitian ini secara umum bertujuan untuk memperoleh gambaran mengenai fungsi fatis partikel le dalam drama serial televisi. Drama televisi yang dijadikan sumber data adalah Zan Jia Na Xie Shir 'Beberapa Masalah Keluarga Kita', episode 1 bagian pertama. Dari 78 buah penggunaan partikel fatis dalam drama televisi itu, partikel fatis le muncul sebanyak 47 kali dengan distribusi 10 buah terletak di tengah kalimat dan 37 buah terletak di akhir kalimat. Hasil penelitian menunjukkan partikel le di tengah kalimat memiliki fungsi mengawali dan mempertahankan pembicaraan, sedangkan partikel le di akhir kalimat mempertahankan dan mengakhiri pembicaraan. Dengan demikian, terdapat kecenderungan bahwa fungsi fatis partikel le tidak selalu berkaitan dengan distribusinya di dalam kalimat.
\end{abstract}

\section{Kata kunci}

Bahasa Mandarin, partikel le, ungkapan fatis

\begin{abstract}
One of the characteristics of non-standard language varieties is employing phatic particles in the beginning of the sentence, in the middle or in the end of it. In Mandarin language, one phatic particle that is commonly used by Mandarin speakers is le particle. This research generally aimed at describing the functions of phatic particle le found in television drama series. The series from which the data were gathered is Zan Jia Na Xie Shir, the first part from the first episode. From 78 phatic particles found in the drama series, of which 47 of them are le as phatic particle; 10 of them are distributed in the middle of the sentence and 37 of them are distributed in the end of the sentence. Based on the result, the function of " $l e$ " in the middle of the sentence is starting a new talk and maintaining a talk. Meanwhile, the function of "le" in the end of the sentence is maintaining a talk and ending a talk. Therefore, it seemed that the function of $l e$ as phatic particle tend to not inline with its distribution in the sentence.
\end{abstract}

Keywords

Mandarin language, le particle, phatic expression/communion

\section{PENDAHULUAN}

Bagaimana menyikapi pertanyaan Ni hao ma ? 'Apa kabar?' yang meluncur dari kawan bicara yang berbahasa Mandarin? Kabar hari ini ataukah kabar kemarin yang ingin diketahui? Apakah kawan bicara memang memerlukan informasi keadaan aktual 
diri kita? Ni hao ma? umumnya digunakan untuk memulai percakapan dan tidak bersifat informatif, melainkan sekedar menunjukkan sikap bersahabat pembicara terhadap kawan bicara atau kerap kita kenal dengan istilah basa-basi. Berdasarkan fungsi bahasanya, kalimat ini memiliki fungsi fatis, yakni sebagai pembuka kanal komuniksi dan fungsi sosial (Cook, 1993:26).

Ungkapan fatis merupakan ciri bahasa lisan dengan ragam tidak baku. Dalam percakapan sehari-hari, ungkapan fatis selain muncul sebagai kalimat juga muncul dalam bentuk partikel. Penutur Bahasa Mandarin sering kali menambahkan partikel $a$, $b a, l a, n e$, dan sebagainya dalam kalimatnya, contohnya:

(1) Xixin dianr a! 'Teliti sedikit dong!'

(2) Zhe zuo lou keneng shi nimen de sushe ba? 'Gedung ini kemungkinan adalah asrama kalian ya?'

(3) Ta zao lai la! 'Dia datang awal lho!'

(4) Jintian wanshang ni qu bu qu ne? 'Malam ini kamu pergi atau tidak sih?'

Partikel-partikel ini merupakan partikel fatis dalam Bahasa Mandarin. Jayanti (2010) dalam penelitiannya tentang partikel fatis dalam acara temu wicara berbahasa Mandarin, dalam satu episodenya, menemukan penggunaan partikel fatis sebanyak 186 buah. Dari jumlah tersebut ditemukan 10 jenis partikel fatis yaitu $a$, ne, ma, ye, ba, la, nei, lie, lo, dan ou. Sementara itu, penulis dalam satu episode drama televisi menemukan penggunaan partikel fatis sebanyak 78 buah, yang terdiri dari partikel $e i, n e, b a, l e, a$, ya, dan ma. Partikel fatis yang paling sering digunakan adalah "le", muncul sebanyak 47 kali. Para ahli linguistik Cina mengemukakan partikel fatis le merupakan partikel yang sering digunakan oleh penutur jati Bahasa Mandarin, tetapi penggunaannya sulit dikuasai oleh pembelajar Bahasa Mandarin (Lü, 1994:36; Li dan Thompson, 2005:218). ${ }^{1}$ Sekalipun demikian, sepengetahuan penulis belum ada yang meneliti partikel ini dari segi kefatisannya. Pada kesempatan ini peneliti terdorong untuk mengisi kekosongan itu.

Partikel fatis dalam Bahasa Mandarin dapat muncul di awal, tengah, atau akhir kalimat. Kridalaksana mengemukakan ungkapan fatis dalam bahasa apapun secara fungsional memulai, mempertahankan, mengukuhkan, atau mengakhiri interaksi verbal (2005:xvi). Terkait dengan fungsi ini, Jayanti (2010) dalam hasil penelitiannya terhadap partikel fatis Bahasa Mandarin yang terletak di tengah dan akhir kalimat menunjukkan bahwa fungsinya berkaitan dengan distribusi partikel itu dalam kalimat. Jadi, jika suatu partikel fatis berdistribusi di tengah kalimat maka fungsinya adalah untuk mempertahankan pembicaraan, lalu jika suatu partikel fatis berdistribusi di akhir

\footnotetext{
${ }_{1}$ Makalah ini hanya mengkaji partikel le sebagai partikel fatis, yang juga sering disebut dengan istilah partikel ekspresif (yuqi zhuci "le") dalam buku tata bahasa Mandarin. Makalah ini tidak membahas "le" sebagai pemarkah aspek perfektif (dongtai zhuci "le"). Oleh karena itu, istilah partikel le atau "le" hanya merujuk kepada le sebagai partikel fatis.
} 
kalimat maka fungsinya adalah untuk mengakhiri pembicaraan.

Penelitian ini mengusung pertanyaan sebagai berikut.

(1) Apa saja fungsi distributif partikel fatis le?

(2) Terkait dengan distribusi partikel fatis le yang tidak pernah muncul di awal kalimat, lalu apakah partikel le tidak memiliki fungsi mengawali pembicaraan?

(3) Adakah kaitan antara makna partikel fatis le dengan fungsi fatisnya?

\section{DATA DAN CAKUPAN PENELITIAN}

Sebagaimana yang telah dikemukakan sebelumnya, partikel le banyak digunakan dalam percakapan sehari-hari. Hal ini sejalan dengan pendapat Kridalaksana (2005:vii) bahwa kategori fatis biasanya terdapat dalam dialog yang umumnya menggunakan ragam tidak baku. Oleh karena itu, data penelitian ini tidak diambil dari bahan ajar Bahasa Mandarin maupun sumber tertulis lain, melainkan dari percakapan antar-tokoh dalam sebuah drama serial televisi yang berjudul Zan Jia Na Xie Shir ‘Beberapa Masalah Keluarga Kita', disiarkan oleh stasiun CCTV 1. Keseluruhan drama ini berjumlah 30 episode, sedangkan yang digunakan sebagai sumber data dalam penelitian ini adalah bagian 1 dari episode pertamanya. Bagian pertama yang hanya berdurasi sepanjang 15 menit ini bercerita mengenai kesibukan kakak beradik Li (dua laki-laki, empat perempuan) yang hendak merayakan ulang tahun perkawinan emas ayah dan ibu mereka. Acara itu diadakan malam hari di rumah keluarga besar $\mathrm{Li}$, setelah semua anggota keluarga pulang dari aktivitas masing-masing. Lima dari enam bersaudara ini sudah menikah, jadi pada hari itu anak dan menantu semuanya berkumpul untuk bersukacita.

Dalam penelitian ini, penulis hanya mengumpulkan partikel le di akhir kalimat yang tidak memiliki fungsi gramatikal sebagai pemarkah aspek perfektif. Partikel le di akhir kalimat yang memiliki fungsi ganda, sebagai pemarkah aspektul sekaligus fungsi fatis, tidak akan diikutsertakan dalam penelitian ini. Partikel fatis le yang diteliti meliputi yang terletak di akhir kalimat dan di tengah kalimat.

\section{TUJUAN DAN KEMANAKWIAN PENELITIAN}

Secara umum penelitian ini bertujuan untuk melengkapi kajian partikel fatis dalam Bahasa Mandarin. Secara khusus penelitian ini bertujuan untuk memperoleh gambaran mengenai fungsi fatis partikel le dalam percakapan sehari-hari.

Peneliti berharap hasil penelitian ini dapat bermakna untuk menambah wawasan bagi peneliti lain yang hendak mengkaji ungkapan fatis dalam Bahasa Mandarin.

\section{LANDASANTEORI}

\subsection{KATEGORI FATIS}

Istilah fatis diilhami dari istilah yang digunakan Malinowski untuk menamakan 
kategori baru dalam pemakaian bahasa yaitu phatic communion (ungkapan fatis) (Sutami, 2005:184). Kridalaksana (2005:vii) menyebut istilah itu kategori fatis dan mengemukakan kategori fatis bertugas memulai, mempertahankan, mengukuhkan, atau mengakhiri pembicaraan antara pembicara dan kawan bicara. Kategori fatis ini tidak dapat diucapkan dalam monolog, biasanya terdapat dalam konteks dialog atau wacana bersambutan, yaitu kalimat-kalimat yang diucapkan oleh pembicara dengan lawan bicara. Kategori ini terdiri dari frase, kata, dan partikel fatis. Dari segi distribusinya dalam kalimat, partikel ini terletak di awal, di tengah (memisahkan frase atau klausa), dan di akhir kalimat.

Akan tetapi, keberadaan partikel fatis dalam kategori fatis Bahasa Mandarin belum disadari sepenuhnya oleh ahli linguistik Cina (Sutami, 2005:183). Partikel fatis, seperti partikel $b a, a$, ne, le, lou, berada di bawah kategori partikel ekspresif, ${ }^{2}$ yakni partikel untuk mengekspresikan emosi (mood) atau nada bicara (tone). Inilah letak perbedaan linguis Cina dengan linguis Barat yang membedakan fungsi fatis dari fungsi emotif yang merupakan refleksi emosional pembicara (Cook:26). Oleh karena itu, penulis mendukung Sutami (2005) yang menggolongkan partikel-partikel yang disebut partikel ekspresif dalam Bahasa Mandarin sebagai partikel fatis dan memuatnya dalam kategori sendiri, yakni kategori fatis. Jayanti (2010) mencatat dua jenis fungsi partikel fatis yang dikemukakan oleh Sutami, yakni: (1) memulai, mengukuhkan, dan mengakhiri percakapan; (2) menyatakan penegasan, menghaluskan maksud pembicaraan, menunjukkan bahwa pembicara dan kawan bicara fokus terhadap pembicaraan mereka, atau juga tidak menyatakan maksud-maksud di atas (berfungsi netral). Karena fokus penelitian ini adalah fungsi partikel fatis le ditinjau dari distribusinya dalam kalimat maka penulis hanya meneliti fungsinya berdasarkan jenis yang pertama (fungsi jenis (1)). Selain itu, untuk meneliti suatu partikel fatis memiliki fungsi menghaluskan atau menegaskan maksud pembicaraan, tidak cukup bila hanya dilihat dari segi distribusi sintaktis. Penelitian untuk fungsi fatis dari jenis (2) perlu ditinjau dari segi teori emosi.

\subsection{PARTIKEL FATIS $L E$}

Sebagaimana yang telah dikemukakan pada subbab di atas, partikel fatis le sering ditemukan dalam percakapan sehari-sehari. Hal ini menandakan luasnya situasi tuturan penggunaan partikel le. Oleh karena itu, makna partikel ini sulit dirumuskan dalam satu kalimat sederhana. Berikut ini adalah makna partikel fatis $l e$ yang penulis simpulkan dari beberapa sumber (Lü Wenhua, 1994; Liu Yuehua, 2003; dan Li dan Thompson, 2005). (1) Menyatakan perubahan keadaan atau munculnya keadaan baru, baik pada waktu sekarang, lampau, maupun yang akan datang (segera terjadi). Liu (2003:383)

2 Dalam Bahasa Mandarin, partikel dibedakan berdasarkan fungsi gramatikalnya, yakni: (1) partikel struktural (jiegou zhuci), (2) partikel aspektual (dongtai zhuci), dan (3) partikel ekspresif (yuqi zhuci) (Norman, 1988:157-158; Guo, 2000:62). 
mengemukakan penggunaan partikel le dalam kalimat perlu dilihat sebagai sebuah strategi yang dipilih oleh pembicara sewaktu menyatakan perubahan keadaan atau munculnya keadaan baru. Kalimat mengenai perubahan keadaan yang menggunakan partikel le dimaksudkan pembicara untuk menarik perhatian kawan bicara sebelum masuk ke pokok pembicaraan ataupun meminta kawan bicara untuk memperhatikan informasi dalam kalimat. Karena pada waktu menyatakan perubahan itu, pembicara juga hendak menyampaikan makna implikatur dari tuturannya. Beberapa makna implikatur yang direprentasikan melalu partikel fatis le adalah: (a) menyangkal asumsi kawan bicara, (b) menyatakan perkembangan terkini dari keadaan yang sudah diketahui sebelumnya, dan (c) menyatakan/menunjukkan tindakan yang akan dilakukan selanjutnya.

(2) Mengakhiri/merampungkan kalimat. Dalam hal ini, partikel le juga berfungsi untuk menandakan berakhirnya topik pembicaraan. Selain itu, Li dan Thompson mengemukakan (2005:242) penggunaan partikel le dengan makna ini terdapat dalam kalimat yang bukan berupa jawaban/respon dari suatu pertanyaan, melainkan kalimat yang diinisiasi pembicara. Penambahan partikel le menjadikan kalimat itu masuk ke dalam konteks situasi pembicaraan dan tidak menimbulkan keambiguan atau pertanyaan dalam benak kawan bicara, seperti "mengapa ia (pembicara) harus mengemukakan hal itu". Selain itu, le juga menunjukkan kepada kawan bicara bahwa kalimatnya sudah selesai, tidak ada yang ingin dikatakan lagi.

(3) Sementara itu, dalam wacana tulis partikel le digunakan apabila subjek kalimat berubah. Jadi, selama subjek tetap sama, sekalipun sedang menceritakan keadaan perubahan, partikel le baru akan digunakan di akhir karangan/cerita (Liu, 2003:384). Penggunaan partikel le dalam kondisi seperti ini menciptakan kesinambungan antar-kalimat.

(4) Pemerincian contoh yang dikemukakan sesuka hati.

\subsection{KARAKTERISTIK KALIMAT DENGAN PARTIKEL EKSPRESIF LE}

Untuk menghindari kesalahan dalam mengidentifikasi le sebagai partikel ekspresif, peneliti berpegang pada karakteristik kalimat dengan partikel ekspresif le yang dikemukakan Yip dan Rimmington (2006:127-128), yakni: (1) memiliki pelengkap penunjuk arah atau pelengkap hasil; (2) terdapat verba yang memiliki makna mulai, berakhir, selesai, muncul, hilang, berubah, dan sebagainya; (3) terdapat adverbia kuaiyao/ jiuyao 'segera akan'; (4) memiliki verba perbuatan atau verba keadaan (umumnya monosilabis) seperti dao 'sampai', bing 'sakit', liang 'terang' yang secara alamiah memiliki kontradiksi terhadap perbuatan/keadaan sebelumnya; atau (5) berupa kalimat dengan predikat nominal mengenai umur, tinggi, berat, dan sebagainya. 


\section{FUNGSI DISTRIBUTIF PARTIKEL FATIS $L E$}

Di bawah ini merupakan hasil penelitian terhadap fungsi fatis partikel le yang ditemukan dalam percakapan drama televisi Zan Jia Na Xie Shir 'Beberapa Masalah Keluarga Kita'. Dari sampel partikel fatis le yang muncul sebanyak 47 kali, partikel le yang terletak di tengah kalimat berjumlah 10 buah; partikel le yang terletak di akhir kalimat berjumlah 37 buah. Analisis dilakukan terhadap empat partikel le di tengah kalimat dan empat partikel le di akhir kalimat. Pemilihan delapan partikel le yang diikutsertakan dalam analisis dilakukan secara acak. Hasil analisis disajikan berdasarkan distribusi partikel le dalam kalimat.

\section{1 “LE” DITENGAH KALIMAT}

Dari 10 buah partikel fatis le yang ditemukan di tengah kalimat, 5 buah terletak di belakang kata xing 'baik' dan 3 buah terletak dibelakang kata dui 'benar'. Berikut ini adalah pembahasan mengenai empat partikel le di tengah kalimat.

Shuzhen: (berbicara sendiri setelah menutup telepon) Xiuyan you bu zhidao feng nar qu le.

Lagi-lagi tidak tahu Xiuyan pergi ke mana.

Yongshun: Ei, Ma, dui le (01), deng ta hui lai ni ke dei haohao ma ma Xiuyan. Zhe liang tian you yige daben ba ta songdao hui jia. Wo dou kanjian liang hui le (02). (Kepada kakak iparnya) Pai wo ne? shi ma? Zhengzai pai de wo shì momo wu yu liang yanlei.

'Ma, oh ya, setelah dia pulang mama harus memarahi Xiuyan dengan sungguh-sunguh. Dua hari belakangan ini sebuah Mercy mengantarnya pulang. Saya melihatnya dua kali lho.'

(Kepada kakak iparnya) 'Sedang merekam saya? Iya kan? Yang sedang direkam adalah air mata yang tidak bisa berkata apa-apa.

Shuzhen: Xing le (03), ni shao shuo liang ju ba. Ni zhen shi...

‘Cukuplah. Kamu jangan banyak omong ya. Kamu benar-benar...

Yongshun: Haishi xiang zhe ziji guinü. Zhende, wo zhende ba wo de xinlihua. Yíding yào lù xiàlái.

'Masih saja memihak anak sendiri. Sungguh, saya benar-benar mengemukakan kata hati saya. Pastinya harus direkam.

Shuzhen: Xing le (04).

Cukuplah.

Dialog (1) merupakan percakapan antara Shuzhen (ibu mertua) dan Yongshun (menantu pria). Pada awalnya mereka berada di ruangan yang berbeda; Shuzhen berada 
di ruang tamu, Yongshun berada di dekat ruang makan. Dalam dialog (1), partikel le yang terletak di tengah kalimat adalah partikel le (01) dan (03). Partikel le (01) terletak setelah kata dui 'benar', sedangkan partikel le (03) terletak setelah kata xing 'baik'. Makna partikel le (01) tidak termasuk dalam kategori menyatakan perubahan keadaan, melainkan adalah penanda jeda sebelum masuk ke pokok pembicaraan. Setelah mengatakan "dui" Yongshun belum akan mengakhiri kalimatnya, sebaliknya, baru akan memasuki pokok pembicaraan. Namun, sebelumnya ia memberikan jeda terlebih dahulu dengan menambahkan partikel le. Hal ini terlihat dari letak pokok pembicaraan yang berada setelah partikel le. Yang menjadi pokok pembicaraan Yongshun adalah " $n i$ ke dei haohao mama Xiuyan", yakni meminta Shuzhen, yang juga ibu mertuanya, untuk memarahi Xiuyan yang tidak lain adalah istri Yongshun. Dengan demikian, penulis berkesimpulan partikel le (01) bermakna sebagai pemarkah jeda, sekalipun dalam teori yang melandasi penelitian ini, tidak disebutkan makna partikel le yang seperti ini.

Sementara itu, partikel le (03) terdapat dalam kalimat xing le, ni shao shuo liang ju ba yang secara garis besar Shuzhen meminta Yongshun untuk jangan banyak omong, berhenti menyindir Xiuyan. Pada waktu itu Yongshun tidak sedang berbicara kepada Shuzhen, melainkan sedang mengalihkan pembicraan kepada kakak iparnya. Sekalipun demikian, perkataan Yongshun itu masih ditujukan untuk Shuzhen. Yongshun berharap dengan menyindir Xiuyan, Shuzhen akan terpicu untuk memarahi Xiuyan. Namun, perkataan itu hanya membuat Shuzhen jengkel terhadap Yongshun sehingga ia meminta Yongshun untuk berhenti berbicara. Oleh karena itu, partikel le (03) memiliki makna untuk menyangkal asumsi yang salah. Selain itu, mengingat Shuzhen tetap menyimak perkataan Yongshun kepada kakak iparnya maka partikel fatis le berfungsi untuk mempertahankan pembicaraan.

Dengan demikian, kedua partikel le ini terletak di tengah kalimat dan berfungsi untuk mempertahankan pembicaraan. Partikel le yang berdistribusi di tengah kalimat dan berfungsi sama seperti ini juga terdapat dalam partikel le yang memiliki makna menyatakan perubahan keadaan yang akan segera terjadi. Contohnya adalah sebagai berikut ini.

(2)

Xiuhong: Pengxin! Pengxin! Jintian shi wo ba ma jinhunri. Zan xian bie ti lihunshi, xing ma?

Pengxin! Pengxin! Hari ini adalah hari perkawinan emas papa, mama saya. Kita jangan ungkit masalah perceraian dulu, bolehkah?

Pengxin: (mengangguk).

Xiuhong: Wo ge he Xiaoxiao jiuyao jiehun le (05), wo xiang gei tamen na yiwan kuai qian. Ni gei tamen ba.

Abang saya dan Xiaoxiao segera akan menikah, saya ingin memberikan sepuluh ribu yuan untuk mereka. Kamu yang berikan ya.

Pengxin: Zhe geniziji gei ba.

Ini kamu berikan sendiri deh. 
Partikel le (05) terletak di belakang kata kerja jiehun 'menikah', tetapi tidak termasuk ke dalam partikel aspektual. Dikarenakan partikel le (05) berada di dalam kalimat yang memiliki adverbia “jiuyao" 'segera akan' sehingga perbuatan (jiehun/ menikah) belum selesai dikerjakan. Partikel le (05) memiliki makna menyatakan perubahan keadaan yang akan segera terjadi. Fungsi Xiuhong menyatakan perubahan dengan partikel le adalah untuk mengalihkan perhatian Pengxin. Berdasarkan diaog (2), Xiuhong pada awal pembicaraan meminta Pengxin untuk tidak mengungkit masalah perceraian mereka di depan ibu dan bapaknya. Kemudian, Xiuhong masih ingin berbicara mengenai topik lain. Dengan menyatakan suatu hal yang akan segera berubah, Xiuhong berharap perhatian Pengxin akan beralih karena kabar yang akan segera terjadi terkesan penting untuk disimak. Selain itu, juga berharap Pengxin tetap mau memperhatikan pembicaraan sebelum Xiuhong masuk ke pokok pembicaraan. Inti seluruh ujaran Xiuyan terdapat di belakang, yakni ia menginginkan Pengxin untuk memberikan uang sebagai hadiah pernikahan adik laki-lakinya. Dengan demikian fungsi distributif partikel le (05) adalah mempertahankan pembicaraan.

Hal menarik dari temuan penelitian ini adalah munculnya satu partikel le di tengah kalimat yang fungsi distributifnya bukan untuk mempertahankan kalimat, sebagaimana yang terdapat partikel le (06) berikut ini.

(3)

Guoli: Anjing! Anjing! Anjing!

Tenang! Tenang! Tenang!

Xiuhua: Nimen rang Guoli shuo. Zenme le Guoli?

Kalian persilakan Guoli bicara dulu. Kenapa Guoli?

Guoli: $\quad$ Nimen lia "banniang", "banlang" jiu zai ba ma houtou. Zhan hao.

Kalian berdua "pendamping wanita", pendamping pria" tepat berada di belakang papa mama. Berdiri dengan baik.

Yongshun: Hao, hao, hao.

Baik, baik, baik.

Guoli: $\quad$ Dui le (06), Pengxin, ni bang wo luyin.

Oh ya, Pengxin, kamu bantu saya merekam.

Pengxin: Wo lai ya, lai.

Saya tangani.

Guoli: Wo zhuchi.

Saya memandu acara.

Partikel le (06) terletak setelah kata dui dan berdistribusi di tengah kalimat, sama halnya dengan partikel le (01), tetapi memiliki fungsi yang berbeda. Guoli berkata "dui $l e^{\prime \prime}$ kepada Pengxin. Sebagaimana yang telah penulis kemukakan sebekumnya, dui le dalam hal ini bukanlah jawaban terhadp suatu pertanyaan maupun peretujuan terhadap suatu informasi yang telah dikemukakan sebelumnya. Partikel le diperlukan untuk mendampingi dui supaya ujaran itu tidak janggal. Pada dialog (3), Guoli sebelumnya sedang berbicara kepada Yongshun, lalu ia beralih berbicara kepada Pengxin sehingga 
akan membingungkan bagi Pengxin apabila Guoli tiba-tiba mengatakan "dui" kepadanya padahal Pengxin tidak sedang bertanya kepadanya-pada waktu itu belum tercipta kontak komunikasi antara Pengxin dan Guoli. Oleh karena itu, Guoli menambahkan partikel le sehingga ujaran itu dapat masuk sesuai konteks dan tidak menimbulkan keambiguan. Jadi, sekalipun partikel le (06) terletak di tengah kalimat, fungsi yang dimilikinya adalah untuk mengawali pembicaraan.

\section{2 “LE” DI AKHIR KALIMAT}

Dua partikel le di akhir kalimat terdapat dalam dialog (1), yaitu partikel le (02) dan (04). Partikel le (02) terletak di akhir kalimat "wo dou kanjian liang hui le" 'saya melihatnya dua kali lho'; sedangkan partikel le (04) terletak di akhir kalimat "xing le" 'cukuplah'.

Partikel le (02) menandakan berakhirnya cerita Yongshun mengenai tokoh Xiuyan (istrinya). Hal itu terlihat dari strategi Yongshun meletakkan partikel le di akhir ceritanya. Yongshun bisa saja menggunakan le pada kalimat sebelumnya "Zhe liang tian you yige daben ba ta song dao hui jia" . Kalimat ini menunjukkan keadaan yang baru-baru ini terjadi dan memiliki salah satu ciri kalimat dengan partikel fatis le, yakni pelengkap hasil (dao dalam song dao) sehingga sahih bila Yongshun menggunakan le di akhir kalimat itu. Apabila le digunakan dalam dua kalimat terakhir, cerita Yongshun akan berbunyi seperti ini: "Zhe liang tian you yige daben ba ta song dao hui jia le 'dua hari belakangan ini sebuah Mercy mengantarnya pulang lho. Wo dou kanjian liang hui le" 'Saya melihatnya dua kali lho'. Akan tetapi, antara kalimat satu dan lainnya menjadi tidak berkesinambungan. Selain itu, apabila Yongshun menggunakan partikel le sebelum ceritanya berakhir, kawan bicara tetap akan mengira Yongshun sudah tidak ingin bercerita dan menganggap saat itu adalah giliran kawan bicara untuk memberikan respon. Oleh karena itu, Yongshun menunda pemakaian le sampai pada akhir cerita. Jadi, penambahan partikel le (2) di akhir kalimat itu berfungsi untuk mengakhiri pembicaraan. Dapat dilihat dalam dialog (1), setelah menyelesaikan cerita mengenai perilaku Xiuyan belakangan ini, Yongshun tidak melanjutkan pembicaraannya dengan Shuzhen, melainkan mengalihkan pembicarannya kepada kakak iparnya.

Kalimat Shuzhen di atas (xing le) merupakan satu-satunya ujaran Shuzhen untuk menanggapi segala ocehan Yongshun. Penambahan partikel le dalam kalimat xing le menjadikan kalimat itu masuk ke dalam konteks pembicaraan. Apabila partikel le dihilangkan, hanya tersisa "xing" 'baik (oke)' yang biasanya merupakan jawaban/ respon persetujuan dari apa yang dikatakan kawan bicara. Li dan Thompson (2005) mengemukakan penggunaan partikel le yang bukan berupa jawaban/respon dari suatu pertanyaan, melainkan kalimat yang diinisiasi pembicara bermakna untuk merampungkan kalimat. Dalam dialog (1) pun dapat dilihat, setelah menambahkan partikel le (04) di belakang kata "xing", Shuzhen tidak mengatakan apa-apa lagi bahkan pembicaraan antara Yongshun dan Shuzhen pun tidak berlanjut lagi. 
Dengan demikian, partikel le (02) dan (04) yang keduanya berdistribusi di akhir kalimat ini bermakna merampungkan kalimat dan berfungsi mengakhiri pembicaraan. Selain dua partikel le yang bermakna merampungkan kalimat, terdapat dua "le" dengan makna lain yang juga berdistribusi di akhir kalimat. Yang menarik dari dua "le" berikut adalah variasi fungsi yang dimilikinya. Contohnya terdapat dalam dialog (4) dan (5) berikut ini.

(4)

Xiurong: $\quad M a, m a$, na ge dianfen wo mei zhaojian.

Ma, ma, saya tidak ketemu sagu itu.

Shuzhen: Huilai wo jiu fang zai zher le. (07)

Sekembalinya, saya letakkan di sini kok.

Xiurong: Ge zheme gao, wo shang nar zhao qu.

Disimpan begitu tinggi, saya sampai cari ke mana-mana.

Partikel le (07) muncul di akhir kalimat "Huilai wo jiu fang zai zher le", tetapi tidak sekedar menandakan berakhirnya kalimat ini. Partikel le (07) bermakna untuk menyangkal asumsi kawan bicara. Dialog (04) merupakan percakapan antara Xiurong (anak) dengan Shuzhen (ibu). Xiurong yang bertugas memasak untuk acara perayaan itu, tiba-tiba keluar dari dapur, mencari ibunya, lalu mengatakan ia tidak menemukan sagu. Perkataan Xiurong ini menyiratkan makna bahwa sagu tidak ada di tempatnya atau mengira Shuzhen telah salah mengingat letak sagu itu. Sementara itu, penambahan partikel le di akhir kalimat Shuzhen menunjukkan itu adalah satu-satunya alasan Shuzhen dan satu-satunya perubahan yang pernah dilakukan Shuzhen terhadap sagu itu sejak sagu itu dibeli dan dibawa pulang, yakni meletakkannya di tempat yang ia sebut. Selain itu, apabila partikel le dihilangkan, kawan bicara masih akan menunggu alasan selanjutnya dari Shuzhen karena kalimat Shuzhen dianggap belum selesai oleh kawan bicara. Jadi, partikel le (07) yang berdistribusi di akhir kalimat ini berfungsi untuk mengakhiri pembicaraan.

Selanjutnya adalah uraian terakhir mengenai partikel fatis le yang terletak di akhir kalimat. Makna yang dimiliki partikel le kali ini adalah menyatakan perkembangan terkini. Contohnya terdapat dalam dialog (5).

(5)

Shuzhen: Pengxin! Lai, ma gen ni shuohua. Xiuhong zheme chang shijian mei huai haizi. Ni ba, ni ma shi bu shi you zhaoji le (08)? Bu yong fachou, ye bu yong zhaoji. Ni kan, ni gen Xiuhong nianqing, shenti hen hao, ganqing you name hao. Na, huai haizi hai bu shi zao wan de shi. Guo liang tian wo zai ling Xiuhong qu kankan Miao daifu.

Pengxin! Sini, mama mau bicara denganmu. Xiuhong sudah begitu lama belum hamil. Papa, mamamu gelisah lagi kan? Tidak perlu cemas, juga tidak perlu gelisah. Kamu lihat, kamu dan Xiuhong muda, sehat, lagi pula perasaan kalian begitu bagus. Hamil juga bukan masalah cepat atau lambat. Dua hari lagi saya bawa Xiuhong periksa ke dokter Miao. 
Partikel le (08) terletak setelah ajektiva zhaoji 'gelisah'dan berada di dalam kalimat yang memiliki adverbia "you" 'lagi'. Li dan Thompson (2005:237) berpendapat adverbia "you" digunakan untuk menghubungkan dua peristiwa dan pada saat yang sama menyatakan perkembangan terkini yang berkaitan dengan peristiwa itu sehingga sering digunakan bersama-sama dengan partikel fatis $l e$. Sebagai catatan, perkembangan terkini itu merupakan peristiwa yang berulang, yang sama dengan peristiwa sebelumnya.

Penggalan dialog di atas diujarkan oleh Shuzhen, ibu mertua Pengxin. Ia hendak menyampaikan kepada menantunya (Pengxin) bahwa sekalipun anak perempuannya (Xiuhong) belum bisa memberikan anak, keluarga Pengxin jangan cemas karena masih ada cara/harapan untuk punya anak. Di dalam ujarannya terdapat kalimat tanya yang diakhiri dengan partikel le. Shuzhen sangat memahami bahwa memiliki generasi penerus keturunan merupakan hal penting dalam budaya keluarga Cina tradisional. Sebagai orang tua, ia pun dapat merasakan kecemasan yang mungkin sedang dialami orang tua Pengxin. Oleh karena itu, ia hendak menanyakan perkembangan terkini dari sikap orang tua Pengxin terhadap kondisi ini melalui kalimat "Ni ba, ni ma shi bu shi you zhaoji le". ${ }^{3}$ Setelah mengemukakan hal ini, Shuzhen tetap melanjutkan pembicaraan mengenai kondisi Xiuhong yang belum bisa memberikan anak. Oleh karena itu, partikel le (08) berfungsi untuk mempertahankan pembicaraan. Temuan ini menunjukkan bahwa partikel fatis le yang terletak di akhir kalimat tidak selalu berfungsi untuk mengakhiri pembicaraan.

\section{KESIMPULAN}

Berdasarkan hasil analisis terhadap partikel fatis le yang terdapat dalam drama televisi Zan Jia Na Xie Shir 'Beberapa Masalah Keluarga Kita'dapat disimpulkan bahwa tiga fungsi distributif, mengawali, mempertahankan, dan mengakhiri pembicaraan semuanya ditemukan dalam partikel fatis $l e$.

Partikel fatis le di tengah kalimat memiliki makna memperbaiki asumsi yang salah, menyatakan perubahan yang akan segera terjadi, dan penanda jeda sebelum masuk ke topik pembicaraan. Tiga dari empat partikel le yang terletak di akhir kalimat memiliki fungsi mempertahankan pembicaraan (partikel le (1), (3), (5)). Sementara itu, satu partikel le di tengah kalimat berfungsi mengawali pembicaraan (partikel le (06)).

Partikel fatis le di akhir kalimat memiliki makna merampungkan kalimat, menjaga kesinambungan dan mengakhiri cerita, menyangkal/memperbaiki asumsi yang salah, dan menyatakan perkembangan terkini. Tiga partikel le di akhir kalimat berfungsi

\footnotetext{
${ }^{3}$ Li dan Thompson (2005:238), berpendapat dalam kalimat tanya mengenai perkembangan keadaan dari seseorang yang kita kenal, partikel le digunakan untuk menghaluskan pertanyaan atau menunjukkan sikap bersahabat. Oleh karena itu, penulis mengasumsikan partikel le (08) juga memiliki makna seperti itu. Namun, menentukan suatu kalimat menjadi lebih halus atau lebih bersahabat dengan menambahkan bentuk tertentu tidak lengkap bila tidak ditinjau dari segi emosi. Sayangnya penelitian ini tidak menyentuh ranah emosi, maka asumsi ini belum dapat dibuktikan kali ini.
} 
mengakhiri pembicaraan (partikel le (02), (04), (07)); sedangkan partikel le (08) berfungsi mempertahankan pembicaraan.

Selanjutnya, penulis tidak selalu menemukan kaitan antara makna partikel le dengan fungsi fatisnya. Misalnya partikel le yang bermakna memperbaiki asumsi yang salah memiliki dua fungsi, yakni mempertahankan pembicaraan dan mengakhiri pembicaraan (lihat partikel le (3) dan (7)). Di sisi lain, dua partikel le yang bermakna mengakhiri kalimat/cerita (partikel le (02) dan (04) memiliki fungsi yang sama, yakni mengakhiri pembicraaan. Penulis pun menyadari sulit dilakukan generalisasi mengenai hal ini karena minimnya data penelitian ini.

Selain itu, temuan lain dalam penelitian ini terkait dengan makna partikel le. Tumpang tindih makna partikel le yang dikemukakan para ahli menunjukkan belum ada kesepakatan dalam menjelaskan le sebagai partikel fatis dan menandakan penggunanaanya yang luas serta kompleks. Makna le yang ditemukan dalam data tidak sepenuhnya memenuhi makna-makna "le" yang sudah dikemukakan para ahli, seperti le dalam dui le dan xing le yang terletak di tengah kalimat. Melihat kemunculannya sebagai tanggapan seharusnya termasuk dalam makna merampungkan kalimat (Li dan Thompson, 2005), tetapi hal itu tidak cocok karena dalam data kedua le terletak di tengah kalimat, kalimatnya pun belum selesai. Oleh karena itu, untuk menentukan maknanya penulis melihat kelanjutan isi klausa yang mendampinginya.

\section{DAFTAR PUSTAKA}

\subsection{SUMBER BUKU}

Cook, Guy. Discourse. Hongkong: Oxford University. 1993.

Guo, Zhenhua. A Concise Chinese Grammar. Beijing: Sinolingua. 2000.

Jayanti, Septhany. "Partikel Fatis Bahasa Mandarin dalam Acara Temu Wicara Televisi". Skripsi Sarjana FIB UI. Depok: Universitas Indonesia. 2010.

Kridalaksana, Harimurti. Kelas Kata dalam Bahasa Indonesia. Jakarta: PT. Gramedia. 2005.

. "Pengantar Ilmiah: Dari Fungsi Fatis ke Ungkapan Fatis" dalam Sutami Ungkapan Fatis dalam Pelbagai Bahasa. Depok: PLL FIB UI. Hlm: v-xvi. 2005.

Li, C.N. dan S.A. Thompson. Hanyu Yufa (Mandarin Chinese). Taipei: The Crane Publishing. 2005.

Liu, Yuehua et.al. Shiyong Xiandai Hanyu Yufa. Beijing: Shangwu Yinshuguan. 2003.

Lü, Wenhua. Duiwai Hanyu Jiaoxue Yufa Tansuo. Beijing: Yuwen Chubanshe. 1994.

Norman, Jerry. Chinese. Cambridge: Cambridge University Press. 1988.

Sutami, Hermina. "Fungsi Komunikatif Partikel Fatis dalam Bahasa Mandarin" dalam Sutami, Ungkapan Fatis dalam Pelbagai Bahasa. Depok: PLL FIB UI. Hlm:183-200. 2005. 
Waridin. "Ungkapan Fatis dalam Acara Temu Wicara Televisi”. Tesis Pasca-Sarjana FIB UI. Depok: Universitas Indonesia. 2008.

Yip, Po-Ching dan Don Rimmington. Chinese: An Essential Grammar. New York: Routledge. 2006.

\subsection{SUMBER ELEKTRONIK}

http://www.youtube.com, diunduh pada 6 Juli 2012 pukul 11:22 WIB. 